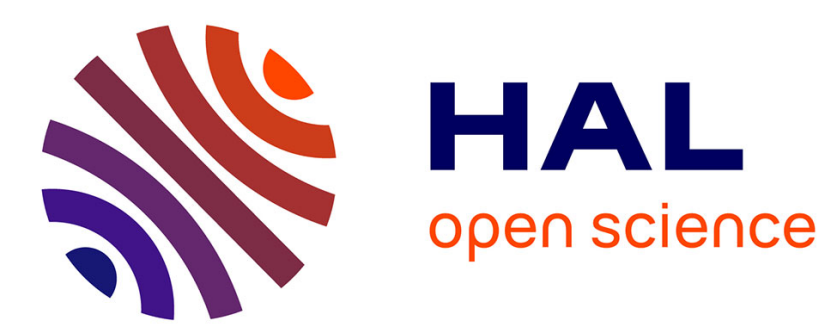

\title{
Passive obduction and gravity-driven emplacement of large ophiolitic sheets: The New Caledonia ophiolite (SW Pacific) as a case study?
}

\author{
Y. Lagabrielle, A. Chauvet, M. Ulrich, S. Guillot
}

\section{To cite this version:}

Y. Lagabrielle, A. Chauvet, M. Ulrich, S. Guillot. Passive obduction and gravity-driven emplacement of large ophiolitic sheets: The New Caledonia ophiolite (SW Pacific) as a case study?. Bulletin de la Société Géologique de France, 2013, 184 (6), 10.2113/gssgfbull.184.6.545 hal-01257702

HAL Id: hal-01257702

https://hal.science/hal-01257702

Submitted on 19 Jan 2016

HAL is a multi-disciplinary open access archive for the deposit and dissemination of scientific research documents, whether they are published or not. The documents may come from teaching and research institutions in France or abroad, or from public or private research centers.
L'archive ouverte pluridisciplinaire HAL, est destinée au dépôt et à la diffusion de documents scientifiques de niveau recherche, publiés ou non, émanant des établissements d'enseignement et de recherche français ou étrangers, des laboratoires publics ou privés. 
2

3
Passive obduction and gravity-driven emplacement of large ophiolitic sheets : The New Caledonia ophiolite (SW Pacific) as a case study?

Obduction passive et mise en place gravitaire des grandes nappes

ophiolitiques : les ophiolites de Nouvelle-Calédonie (SW Pacifique) sont-elles un cas d'école?

by, par

Yves Lagabrielle $\left(1^{\circ}\right)$, Alain Chauvet (1) , Marc Ulrich (2) and Stéphane Guillot(2).

(8)

18

(1) : Université Montpellier2-CNRS, UMR Géosciences Montpellier, CC 60, UM2, Place Eugène Bataillon, 34095 Montpellier cedex 5, France.

$\left({ }^{\circ}\right)$ : corresponding author : yveslagabrielle@yahoo.fr

7 (2) Université Grenoble 1-CNRS, UMR 5275 ISTerre, Université Grenoble 1, 38041, Grenoble cedex, France 


\section{Abstract}

The $300 \mathrm{~km}$ long allochtonous sheet of oceanic mantle forming the New Caledonia ophiolite displays three specific characters : 1 . the ophiolite pile lacks concordant sheeted dykes and pillow basalt layers ; 2 . the ophiolite, refered to as the Peridotite Nappe, is thrusted over the basaltic formations of the Poya terrane which are classicaly thought to originate from a different oceanic environment; 3 . The basal contact of the ultramafic sheet is remarkably flat all along New-Caledonia and the Peridotite Nappe has not been thickened during obduction, rather it experienced significant extension. This suggests that the peridotites have not been emplaced by a tectonic force applied to the rear. New petrological and geochemical results obtained from mantle rocks finally show that the Poya terrane may originate from the same oceanic basin as the peridotites. In this article, we consider such possible cogenetic links and we propose a simple model for the obduction of the New Caledonia ophiolite in which the Poya basalts represent the original cover of the Peridotite Nappe. We infer that continuous uplift of the subducted units buried beneath the oceanic lithosphere in the northern part of New Caledonia drove passive uplift of the ophiolite and led to erosion and to initiation of sliding of the basaltic layer. During the Priabonian (Latest Eocene), products of the erosion of the basaltic layer were deposited together with sediments derived from the Norfolk passive oceanic margin. These sediments are involved as tectonic slices into an accretionary wedge formed in response to plate convergence. The volcaniclastic sedimentation ends up with the emplacement of large slided blocks of basalts and rafted mafic units that progressively filled up the basin. Obduction process ended with the gravity sliding of the oceanic mantle sheet, previously scalped from its mafic cover. This process is contemporaneous with the exhumation of the HP-LT units of Pouebo and Diahot. Gravity sliding was facilitated by the occurrence of a continuous serpentine sole resulting from metasomatic hydratation of mantle rocks which developed during the uplift of the Norfolk basement and overlying Diahot and Pouébo units. Progressive emersion of the obducted lithosphere allowed subsequent weathering under subaerial, tropical conditions

Key words : New Caledonia, Peridotite nappe, Poya terrane, HP-LT units exhumation, gravity sliding, passive obduction.

\section{Résumé}


61 La nappe de manteau de Nouvelle-Calédonie, s'étendant sur $300 \mathrm{~km}$ de long montre trois caractéristiques importantes : (1) La succession ophiolitique ne contient ni dykes, ni basaltes

63 92 en coussin, (2) l'ophiolite est charriée sur des formations basaltiques (nappe de Poya) que l'on considère classiquement comme originaires d'un bassin océanique différent de celui d'où est issu le manteau, et (3) le contact basal de la nappe ultrabasique est remarquablement plat tout le long de lîle et celle-ci n'a pas été épaissie durant l'obduction. Cela suggère que les péridotites n'ont pas été mises en place en réponse à une poussée tectonique arrière. De nouveaux résultats pétrologiques et géochimiques obtenus sur l'ophiolite montrent en réalité que les basaltes de Poya peuvent être extraits de la fusion du manteau de l'ophiolite. Nous proposons donc un nouveau modèle pour l'obduction, dans lequel les basaltes de Poya forment la couverture initiale primitive du manteau de la nappe des Péridotites. La surrection progressive des unités profondes enfouies lors de la subduction de la lithosphère du bassin sud-Loyauté à l'Eocène, a permis le soulèvement passif de l'ophiolite et l'érosion puis le glissement des unités basaltiques. Durant le Priabonien, l'accumulation des produits de l'érosion de la couche des basaltes et de la marge passive de Norfolk ont formé les séquences de flysch comprenant localement des débris basaltiques grossiers. Ces sédiments font partie d'un prisme d'accrétion tectonique construit en réponse à la convergence au front de la subduction. La sédimentation détritique se termine par la mise en place de grandes unités basaltiques glissées qui comblent le bassin. Le processus de l'obduction se termine par le glissement gravitaire de l'écaille de manteau océanique sur les basaltes. Cet événement est contemporain de l'exhumation des unités HP-BT de Pouébo et du Diahot. Le glissement gravitaire a été facilité par la présence sous l'ophiolite, d'une semelle continue de serpentines résultant de l'interaction du manteau avec des fluides métasomatiques remontant durant l'exhumation des unités enfouies pendant la subduction continentale. L'émersion progressive de la lithosphère obduite a placé le manteau dans des conditions d'altération supergène tropicale-

Mots clés : Nouvelle-Calédonie, nappe des Péridotites, Nappe de Poya, exhumation, unités $H P-B T$, glissement gravitaire, obduction passive. 


\section{Introduction}

New-Caledonia consists of a $300 \mathrm{~km}$ long allochtonous sheet of oceanic mantle, the Peridotite Nappe, lying in tectonic contact over the Norfolk-New Caledonia continental block (Avias, 1967; Paris, 1981 and references herein). Obduction is thought to have followed subduction and subsequent closure of back-arc and forearc oceanic domains during the Late Eocene (Cluzel et al. 2001; Crawford et al. 2003; Schellart et al. 2006; Wattham et al. 2008). Constraints for the timing of the exhumation of subducted terranes are provided by studies of the northern regions of New Caledonia where Eocene HP-LT units of oceanic and continental origin are exposed. For this reason, New Caledonia is a key region for studying the processes of obduction and related subduction-exhumation of arc and back-arc basins fragments.

However, despite numerous recent investigations, the successive stages of the obduction process of the Peridotite Nappe are still a matter of debate and various models have been proposed successively in the last 10 years (Cluzel et al. 2001; Crawford et al. 2003; Schellart et al. 2006; Wattham et al. 2008; Ulrich et al. 2010; Titus et al. 2011; Cluzel et al. 2012). One cause of such uncertainties is that the New Caledonia ophiolite pile lacks concordant sheeted dykes and pillow basalt layers. In addition, the ultramafic sheet is thrust over basaltic formations of the Poya Terrane which are classicaly thought to originate from a different oceanic environment. New petrological and geochemical results obtained by Ulrich et al. (2010) allow re-considering the possible cogenetic links between the Poya Terrane and the mantle rocks of New Caledonia. In this article, we examine how these new results modify our understanding of the geodynamics of this region. In particular, we propose a simple model for the obduction of the New Caledonia ophiolite in which the Poya basalts represent the original cover of the Ultramafic Nappe. This model highlights the role played by regionalscale gravity sliding of large mafic and ultramafic sheets as a response to the exhumation and rapid uplift of subducted units.

\section{Geodynamical setting of New Caledonia}


123 New Caledonia is located at the junction between two ocean basins displaying contrasting 124 ages and origins: the New Caledonia basin to the west and the Loyalty basin to the east (fig. 125 1). The New Caledonia basin basement is made up of thinned continental crust to the north 126 and of oceanic crust of Cretaceous age to the south (Lafoy et al. 2005; Collot et al., 2008). 127 The Loyalty basin is a remnant of a wider oceanic domain, the north-eastern part of which 128 disappeared in the west-dipping Vanuatu subduction initiated $12 \mathrm{My}$ ago (Auzende et al., 1995; Ruellan and Lagabrielle, 2005). It is separated by the N140 trending Loyalty Ridge into

130 two basins, the North Loyalty basin and the South Loyalty basin. The Loyalty Ridge is a

131 discontinuous bathymetric high formed by evenly-spaced seamounts, the shallowest 132 forming the Loyalty Islands (fig. 1). Its origin remains unclear due to the lack of age 133 constraints. The root of the Loyalty Ridge has been interpreted as the remnant of an extinct 134 arc often referred to as the Loyalty arc in the literature (Cluzel et al. 2001 and references herein). It likely relates to the northeast-dipping subduction of oceanic crust which initiated east of the Northfolk ridge during the Late Cretaceous-Paleocene and lasted until the obduction of the New Caledonia ophiolites during the Priabonian (37-34 Ma) (Aitchison et al. 1995; Eissen et al. 1998; Cluzel et al., 2001) (fig. 3). The oceanic basement of the North Loyalty basin is considered to have spread along a N100 trending spreading center, at the rear of the Loyalty arc. This back-arc basin opened from 43 to $35 \mathrm{Ma}$ (Middle-Late Eocene), that is during the emplacement of the New Caledonia ophiolites and the exhumation of the HP-LT northern units of the main island (fig. 3). At the southern tip of the Loyalty ridge, the South Loyalty basin connects to the South Fiji Basin which opened from 35 to $15 \mathrm{Ma}$ (Herzer et al. 2011).

To the north of New Caledonia, the Norfolk Ridge has an arch-shape and links up with the EW trending d'Entrecasteaux Ridge colliding itself with the current Vanuatu or New Hebrides subduction zone (fig. 1). Based on dating of dredged basaltic samples, Maillet et al. (1983) suggested that the d'Entrecasteaux Zone might represent the northern arcuate extension of the Loyalty Eocene subduction/obduction zone. The easternmost basement of the

151 d'Entrecasteaux Ridge was drilled at ODP Sites 831 and 828 (Bougainville Guyot). It was 152 shown to consist of $37 \mathrm{Ma}$ old andesitic breccias derived from a submarine arc volcano 153 (Baker et al., 1994) and of primitive arc tholeiitic appropriate for a forearc setting (Coltorti et 154 al. 1994). These results suggest that the d'Entrecasteaux Ridge contains relicts of an island 
arc/forearc system that may belong to the northern portion of the extinct Late Eocene Loyalty arc. In addition, Middle to Late Eocene andesitic volcano-clastic turbidites from a submarine fan were recovered from the North Loyalty Basin, south of the d'Entrecasteaux Ridge, at DSDP Site 286 (Andrews et al., 1975). These data are consistent with the hypothesis that the Loyalty Ridge developed in response to the Eocene Loyalty subduction (fig. 1). This subduction resumed with the obduction of the New Caledonia ophiolite.

\section{The New Caledonia ophiolite and the obduction-related units}

\section{a. The Peridotite Nappe, the pre-obduction dikes and the amphibolites}

To the north of New Caledonia, peridotites are found as a series of klippen aligned in the N140 direction, along the western coast of the main island (fig. 2) (Guillon and Routhier, 1971). By contrast, mantle rocks exposed in the Massif du Sud represent almost $100 \%$ of the surface of southern New Caledonia. Rare gabbros representing basal sections of crustal magma chamber are exposed in the Massif du Sud. The peridotites might have been covered initially by a more complete crustal sequence. We further discuss the possible reasons why most of the mafic terms are lacking.

The basal layer of the Peridotite Nappe is formed of a porphyroclastic serpentine mylonite, the serpentine sole, 20 to $100 \mathrm{~m}$ thick. Large scale normal faulting is frequently observed in the serpentine sole as well as in the bulk ultramafic sheet (Lagabrielle and Chauvet, 2008). Shear sense criteria from the sole locally indicate southwest directed shearing, a direction consistent with the kinematics infered for the obduction (Cluzel et al., 2012).

According to Ulrich et al. (2010), a large proportion of the ophiolite mantle of New Caledonia is composed of highly depleted harzburgites ( \pm dunites) with characteristic U-shaped bulkrock rare-earth element (REE) patterns, as shown by analyses performed in Koniambo and Thiébagi massifs and in Massif du Sud. In contrast, Iherzolites in the northernmost klippen, such at Poum Peninsula, display spoon-shaped REE patterns. The major whole rock and isolated mineral element and REE content of these Iherzolites are indicative of abyssal environments; in particular, their significant LREE enrichment is best explained by partial melting in a spreading ridge, followed by near in-situ refertilization from deeper mantle 
melts. These new data led Ulrich et al. (2010) to consider that the Iherzolites likely represent the equilibrium residue of the undepleted MORB terrane formed during the opening of the South Loyalty basin, from Late Cretaceous to Paleocene. This MORB province might represent a possible source for the basalts of the Poya terrane. In contrast, spinel data of the most depleted harzburgites of New Caledonia, highlights strong forearc affinities. Their compositions are best modeled by hydrous melting of a source that had previously experienced depletion in a spreading ridge. Accordingly, the two melting events in the New Caledonia ophiolite recorded the rapid transition from oceanic accretion to convergence in the South Loyalty basin during the Late Paleocene, with initiation of a new subduction zone at, or near the ridge axis during the Earliest Eocene (Ulrich et al. 2010; Cluzel et al. 2012; fig. 3).

The degree of serpentinization affecting the whole peridotite nappe increases from top to bottom from less than $50 \%$ up to $100 \%$ within the serpentinite sole (Orloff, 1968). Locally, at the hectometre scale, the uppermost part of the peridotite nappe is devoid of serpentine minerals (Ulrich, 2010). According to Raman spectrometry, the serpentine minerals are dominated by lizardite (up to 90\%) while the HP polymorph, antigorite, only crystallized in veins within the serpentinite sole. Ulrich et al. (2011) relate this contrasted bottom to top serpentinization to an upward hydration of the Peridotite Nappe by metasomatic fluids released from the downgoing slab during the Eocene convergence. The rare occurrence of antigorite within the sole is interpreted as related to hotter fluid circulation ( $\mathrm{T}>400^{\circ} \mathrm{C}$ ) when the HP-LT Diahot units were rising up beneath the ophiolite. As further discussed, this result accounts for the creation of a major rheological discontinuity forming the entire basal sole of the ultramafic sheet.

Felsic dikes cutting through the Massif du Sud peridotites have been dated at 53 Ma by Cluzel et al. (2006). The dikes include four main rock types : granitoids, boninite-like andesitic shallow intrusive rocks, high-Mg microgabbro/tonalites, and dolerite of island arc tholeiitic affinities. They are interpreted as slab melts and supra-subduction zone magmatic products. This strongly constrains the timing of incipient convergence at the Eocene Loyalty subduction zone and is consistent with the hypothesis that subduction-related magmatism began during the Early Eocene, probably at a spreading center (Ulrich et al. 2011 ; Cluzel et 
al. 2012).

221 Amphibolite lenses locally crop out beneath the serpentinite sole, at the base of the 222 Peridotite Nappe. They recrystallised in the high-temperature amphibolite facies and display 223 the geochemical features of MORB with a slight Nb depletion (Cluzel et al. 2012). 224 Thermochronological data from hornblende, zircon and sphene reveal that these mafic rocks 225 recrystallised at $\sim 56 \mathrm{Ma}$ with peak conditions of ca $0.5 \mathrm{GPa}$ at ca $800-950^{\circ} \mathrm{C}$. These mafic 226 units are regarded are tectonic slices from the South Loyalty basin oceanic crust, thus 227 belonging to the lower plate of the subduction/obduction system. They recrystallised when 228 they subducted below young and hot oceanic lithosphere (Cluzel et al. 2012). Finally, the presence of these amphibolite lenses and the occurrence of slab melts at $\sim 53$ Ma collectively suggest that subduction inception occurred at, or near to the spreading ridge of the South Loyalty Basin at $\sim 56 \mathrm{Ma}$.

A major feature of the Peridotite Nappe is that it exhibits a very simple structure and lies undeformed above a remarkably flat, sub-horizontal fault. This simple geometry sharply contrasts with the complex structure of the underlying Poya terrane characterized by imbricated folds and thrusts, demonstrating significant shortening during tectonic emplacement. By contrast, the Peridotite Nappe does not show any major internal thrusts and therefore did not experience thickening during its tectonic emplacement. The lack of contractional deformation affecting the Peridotite Nappe is confirmed by the structure of the pre-obduction, $53 \mathrm{Ma}$ old dikes, which lie remarkably undeformed except in the

\section{b. The Poya Terrane and the Tertiary flysch units}

A tectonic unit made up of basalts with an oceanic affinity, named the Poya nappe or Poya terrane (Cluzel et al., 2001), systematically underlies the Peridotite Nappe. This basalt unit is well developed beneath the peridotite klippen of the western coast and forms a thin, almost continuous level beneath the mantle rocks of southern New Caledonia. The Poya terrane is composed of pillow basalts and dolerites with minor abyssal argilites that contain 
251 Campanian to Late Paleocene or Early Eocene radiolarians (Cluzel et al. 1994 ; Aitchison et al. 2521995 ; Cluzel et al. 1997; Eissen et al. 1998; Cluzel et al. 2001). MORB-type tholeiites 253 dominate (ca. 90\%) but minor back-arc basin basalts (BABB, ca. 5\%), and ocean island basalts 254 (OIB) are also present. The back-arc and ocean island basalts probably represent small seamounts erupted on older (Campanian-Early Eocene) MORB crust (Ulrich et al., 2010).

256 Fresh dikes and glassy pillow lavas of boninitic composition are found in rare outcrops of the 257 Poya terrane. Isotopic data demonstrate that these rocks are petrogenetically and 258 tectonically unrelated to the rest of the magmatic terrane (Cameron, 1989). The New 259 Caledonian boninites probably have formed rapidly after the inception of the subduction 260 zone since partial melting for boninitic magmas requires high temperatures (Arndt, 2003).

The Poya nappe has been tectonically emplaced over a composite flysch formation of Late 263 Eocene age. In northern New Caledonia, the Lutetian flysch deposits have recorded the 264 increase in turbidite supply from a terrigenous source. Flysch sections from Koumac and Gomen are characterized by an input of iron and aluminium, a feature interpreted as an echo of weathering and erosion of a continental province (Maurizot, 2011). In southern New Caledonia, the base of the sequence consists of Late Bartonian - Early Priabonian (ca. $40 \mathrm{Ma}$ ) pebbly shallow water limestones lying unconformably upon eroded pre-Cretaceous to midEocene terranes. These lowermost levels underlie marls and calcareous sandy marls which accumulated into a rapidly subsiding basin (Cluzel et al., 2001). These deposits, forming the "lower flysch", progressively change into alternating sandy marls or calcarenite and marls and are overlain by the "upper flysch". The "upper flysch" is an upward coarsening sequence toped by an olistostrome that reworks all the components of the sedimentary cover of the Norfolk basement, including clasts of the Late Eocene bioclastic limestone and the flysch itself (Cluzel et al., 2001). In southernmost New Caledonia, the Eocene flysch includes the Nouméa-Bourail flysch of Late Bartonian to Late Priabonian age (37-34 Ma; Paris, 1981). This upper flysch, well exposed around Nouméa (fig. 1), is 1500 to 3000 m thick. It ends up with fine-grained calcareous turbidites showing basaltic volcaniclastic intercalations and coarsening upward into an olistostrome containing dominant basalt blocks (Cluzel et al., 2001 and references herein). This clastic formation is remarkably devoid of any ultramafic debris, implying that the ultramafic rocks were not in a position to feed the flysch basin and were not widely exposed to the surface at this stage of the orogenic 
283

284

285

286

287

288

289

290

291

292

293

294

295

296

297

298

299

300

301

302

303

304

305

306

307

308

309

310

311

312

313

314

evolution.

A flysch formation partially fed by an ultramafic source has been mapped along the east coast of New Caledonia near Nepoui (fig. 1) (Coudray, 1975; Paris et al., 1979). The Nepoui flysch, 300-500 m thick, stratigraphically overlies the Poya terrane and in turn tectonically underlies the Peridotite Nappe (Cluzel et al., 2001). This geometry is consistent with an interpretation as a piggy-back basin transported by the Poya Nappe during obduction (Cluzel, 1998). The Népoui flysch includes dominant mafic and carbonate clasts. Ultramafic clasts are rare except in two levels at the base and at the summit of the formation. They are mixed with detrital chromite grains from proximal sources and derive from a strongly weathered peridotite. Therefore, these clasts may represent debris transported from the advancing Peridotite Nappe. However, since serpentine slices are also present within the Poya basalts, a single derivation from the Poya terrane cannot be ruled out (Cluzel et al., 2001). The exact age of the Nepoui flysch is not certain, but a post-Late Bartonian age is assigned to the upper levels of the flysch based on the occurrence of carbonate olistolith containing Late Bartonian faunas (Cluzel et al., 2001 and references herein).

The volcanic rocks reworked in the Nouméa-Bourail flysch display undepleted and depleted MORB signatures and are obviously reworked from the Poya Terrane (Cluzel et al., 1997). Therefore, the progressive increasing supply of mafic detritus in the upper flysch is the record of the approach of the mafic Poya Terrane allochthon towards the foreland basin of the Late Eocene orogeny. It must be noticed that the arrival of the basaltic allochthon sheet occurred during the final stages of the post-collision exhumation of the metamorphic terranes exposed in northern New Caledonia, as reported in the following section.

\section{$\underline{\text { c. The Northern High Pressure - Low Temperature units }}$}

A complex of mafic, high pressure-low temperature (HP-LT) metamorphic units is exposed in northern New Caledonia (fig. 2) (Yokoyama et al., 1986; Black et al., 1993; Clarke et al., 1997, Aitchison et al., 1995; Cluzel et al., 2001; Rawling and Lister, 2002; Fitzherbert et al., 2004, 2005; Spandler et al., 2004, 2005; Potel et al., 2006). It forms an elongated foliation anticlinorium, a geometry displaying some similarities with the structure of metamorphic core complexes. This high pressure complex includes two major terranes of oceanic origin. 
315 The exact geometry of these two terranes and their structural relationships are not 316 completely established yet.

317 (1) The highly disrupted Pouébo terrane is represented by dominant metabasite eclogites 318 and glaucophanites and minor serpentine slices. Metabasalts and eclogitized sediments 319 experienced peak metamorphism conditions close to $\mathrm{T}=590^{\circ} \mathrm{C}$ and $\mathrm{P}=1.9-2.3 \mathrm{GPa}$ (Clarke 320 et al., 1997; Carson et al., 2000 ; Spandler et al., 2004). Most of the metabasalts have E321 MORB affinities and might have been erupted in a back-arc ocean basin, possibly the South 322 Loyalty basin (Cluzel et al., 2001). A link between the Poya Terrane and the mafic rocks of 323 the Pouebo Terrane has been made based on geological and geochemical data (Aitchison et 324 al., 1995; Cluzel et al., 2001, Spandler et al., 2004), and a direct correlation of the terranes is 325 supported by zircon U-Pb dating of high-P rocks at 85-55 Ma which fall within the age of the 326 Poya Terrane (Spandler et al. 2005). Therefore, both terranes are suggested to be slices originating from the same oceanic basin, the South Loyalty basin, but the Pouébo terrane reached important depth due to oceanic subduction during the Eocene convergence, whilst the Poya terrane never experienced significant burial.

330 (2) The Diahot blueschist terrane consists of Cretaceaous to Eocene metasediments and 331 minor volcanics which initially formed the sedimentary cover of the eastern continental 332 margin of the Norfolk block. They experienced lower peak metamorphism conditions, 333 around $\mathrm{T}=550^{\circ} \mathrm{C}$ and $\mathrm{P}=1.2 \mathrm{Gpa}$. The Diahot terrane includes sedimentary component 334 related to the erosion of an island-arc (Cluzel et al., 2001). Radiometric dating of prograde and retrograde metamorphic assemblages from the northern HP-LT complex cluster around $44 \mathrm{Ma}$ and $34 \mathrm{Ma}$ respectively (Aitchison et al., 1995; Baldwin et al., 1999; Spandler et al, 2005; Baldwin et al., 2007). This indicates that subduction started at least before $44 \mathrm{Ma}$ and that uplift and unroofing of the metamorphic terranes occurred $10 \mathrm{Ma}$ later, possibly in response to the break of the South Loyalty basin slab (Cluzel et al. 2001). Exhumation of eclogites was almost completed at $34 \mathrm{Ma}$ as shown

342 by apatite fission tracks data (Baldwin et al., 2007). Fluid inclusions data show that unroofing 343 occurred isothermally (Potel et al., 2006). A striking feature is that uplift and exhumation of 344 the HP-LT units occurred in the same time interval as basalts of the Poya nappe, followed by 345 the mantle of the Peridotite Nappe, were emplaced over the Late Eocene flysch sequences in more external domains. This points to a possible relationship between uplift of deep 
crustal levels in northern New Caledonia and late motions of the ophiolite sheet in southern New Caledonia and along the west coast due to gravitational forces along an increasing westward dipping slope. This point is discussed in section 5 below.

\section{New Caledonia Obduction : facts and models}

Among the numerous plate reconstructions of the southwest Pacific and tectonic models of the New Caledonia orogen, most suggest that the South Loyalty Basin was subducted beneath the Loyalty arc during the Eocene (Eissen et al., 1998; Cluzel et al., 2001; Crawford et al., 2003; Spandler et al., 2005 ; Whattam et al., 2008 ; Whattam, 2008). As discussed above, a minimum age of $\sim 53 \mathrm{Ma}$ for the formation of this so-called Loyalty Eocene subduction is provided by geochemical and geochronological studies of the pre-obduction dikes that intrude the mantle section of New Caledonia (Cluzel et al., 2006). Additional informations from the amphibolite lenses associated with the serpentine sole confirm that subduction at the newly formed Loyalty trench initiated at the dying Loyalty basin spreading center around $56 \mathrm{Ma}$ (Cluzel et al., 2012). Obduction was preceded by the shortening of the continental margin of the Norfolk block and by the tectonic emplacement of sedimentary units to form an accretionary wedge at the front of the Loyalty subduction, as shown in the evolutionary model of fig. 4. The Eocene sedimentary formations of New Caledonia have recorded a marked change from a quiet pelagic environment to a tectonically active environment characterized by calciturdites and proximal breccia deposits (Maurizot, 2011). Syntectonic sedimentation into a foreland basin led to the formation of thick Late Eocene flysch sequences mostly fed by the subaquaeous or subaerial erosion of the active tectonic wedge. Stratigraphical data constrain the onset of contraction in the continental margin domain to have occurred around $50 \mathrm{Ma}$ (Ypresian). Thrusting of large units of Eocene sediments occurred during the sedimentation of the youngest flysch sequences, before the tectonic emplacement of the Poya terrane over the Late Eocene flysch (Montagne Blanches subunits, Maurizot, 2011). The final phase of obduction of the New Caledonia ophiolite is constrained to occur between $34 \mathrm{Ma}$ and $27 \mathrm{Ma}$, due to the presence of Uppermost Eocene, pre-obduction sediments beneath the ophiolitic nappe (Formation de la Cathédrale, Cluzel et al. 1998), and to the occurrence of post-obduction, Late Oligocene granitoids crosscutting the peridotites of the Massif du Sud (Cluzel et al. 2005). 
380 Reconstructions of the Late Cretaceous to Cenozoic geodynamics of the SW Pacific region 381 (Cluzel et al., 2001; Crawford et al., 2003 ; Schellart et al., 2006: Wattham et al., 2008) point 382 out the role played by a west-dipping subduction zone active in the region between 82 to 52 383 Ma that accommodated opening of the South Loyalty basin (fig. 3). This was accompanied 384 for authors by fast slab roll-back of the Pacific plate. Assuming continuous spreading 385 between 70 and $50 \mathrm{Ma}$ at a rate of $5 \mathrm{~cm} / \mathrm{yr}$ along the South Loyalty basin spreading center, 386 which is the average rate for the opening of ocean basins in this region, the maximum size of 387 the South Loyalty basin could be about $1000 \mathrm{~km}$. This is large enough to provide a $500 \mathrm{~km}$ 388 long-slab, thereby making the Eocene Loyalty subduction possible. These parameters have been used to construct the evolutionary model in fig. 4.

391 Although based on similar time constraints, the various published models propose different plate tectonic processes at the onset of the Eocene subduction. For Cluzel et al. (2001) the locus for inception of the Loyalty subduction is not really clarified. For Crawford et al. (2003) and Whattam et al. (2008) the NE-dipping Loyalty subduction may have nucleated at $55 \mathrm{Ma}$ at the recently extinct spreading center of the South Loyalty Basin (fig. 3). Eissen et al. (1998) also suggested that inception of NE- dipping subduction in the South Loyalty Basin occurred via reactivation of a recently extinct spreading ridge. For Ulrich (2010) and Ulrich et al. (2010), opening of the South Loyalty Basin during the Campanian to Paleocene was associated with the slab withdrawal east to the Gondwana margin. The formation of undepleted MORB of the South Loyalty basin crust with equilibrium residue in the mantle relates to this event; it was followed by near in-situ refertilization of the peridotites from deeper mantle melts. This led to the formation of the impregnated lherzolites, i.e. the future northern klippen of the New Caledonia ophiolite. A new NE-dipping subduction nucleated at (or near) the spreading ridge center, initiating the closure of the South Loyalty Basin which lasted from Late Paleocene to Early Eocene. The dehydration of the slab is responsible for the second stage of partial melting of the forearc peridotites, probably forming boninitic melts. This allowed the formation of the residual harzburgites, i.e. the future bulk New Caledonia ophiolite. In this model, the future Poya terrane corresponds to the accretionary prism linked to the NE-dipping subduction, it is composed of tectonic slices of basaltic crust 
410 detached from the descending South Loyalty Basin oceanic plate, that is from the lower

411 plate of the subduction system. This point is discussed in the following section.

413 5. Our proposition : a simple model for the emplacement of the New Caledonia mafic and

\section{4 ultramafic ophiolitic units}

The first comprehensive model for the New Caledonia obduction was proposed by Cluzel et al., (2001). The most striking points raised by this model are as follows : (i) the Poya nappe basalts (Poya Terrane) and the Peridotite nappe did not originate from the same oceanic basin ; (ii) the Poya nappe basalts have been scrapped off from an oceanic domain located on the descending plate; (iii) the present-day Loyalty Ridge basement represents the remnant island arc of the Eocene subduction (Loyalty arc); (iv) the Peridotite nappe is the obducted edge of the fore-arc domain of the Loyalty arc. This model contains most of the main elements which compose all published models, especially when considering the evolution of the Loyalty subduction. However, despite its own self-consistency, it cannot solve two remaining questions: (1) Why only rare upper gabbros but no basalts nor sheeted dikes are preserved over the peridotites, and (2) why only the Poya nappe basalts have been captured from the advancing plate and nothing from the rest of this plate?

It has long been considered that the Poya terrane cannot represent the detached cover of 430 the overlying ultramafic terrane (Eissen et al., 1998). This led most authors to build obduction models in which the Poya basalts originated from various settings such as seamounts scrapped from the downgoing oceanic plate during the east-dipping Eocene subduction (Cluzel et al., 2001). However, using equilibrium melting equations, Ulrich et al. (2010) show that melts extracted from the Iherzolites of the Northern Peridotite klippen are compositionally similar to the MORB of the Poya terrane. This is used by these authors to

436 infer that the ultramafic nappe and the mafic Poya terrane represent oceanic lithosphere of a single marginal basin that formed during the late Cretaceous.

Following Ulrich et al., (2010) we may now consider that basaltic formations similar to the Poya MORB-type lavas once formed the stratigraphical cover of the New Caledonia peridotites. Moreover, geochemical data of Marchesi et al. (2009) show that the highly 
depleted harzburgites of the Massif du Sud are residues after high degrees (20-30\%) of partial melting, generating liquids with a geochemical signature transitional between those of island-arc tholeiites and boninites. This suggests that the rare boninites erupted over the Poya basalts could derive from the melting of mantle source similar to the Massif du Sud peridotites. Moreover, it must be noticed that hydrous remelting of the oceanic mantle only occurs in the mantle wedge of the upper plate of any subduction zone. This constraints the boninitic lavas of the west coast of New Caledonia to originate from the upper plate of the Loyalty subduction complex. Since the MORB basalts and the boninitic dike and lavas are closely associated within the Poya Terrane, we may therefore conclude that both the mantle rocks and the mafic units forming the New Caledonia ophiolite originated from the upper plate of the Loyalty subduction, that is from the eastern flank of the South Loyalty spreading center (Fig. 3).

As reported above, a crucial feature of the New Caledonia tectonic pile is that the basalt formations are found beneath the mantle rocks sheet. Taking into account the " unique origin " for the complete mafic-ultramafic pile of New Caledonia as proposed here, the only scenario able to account for such a geometry is that the original oceanic lithosphere belonging to the upper plate has experienced a diverticulation process during its final emplacement over the Norfolk continental basement. Diverticulation within a tectonized sequence, a term defined by Maurice Lugeon, allows upper tectonic units to be overthrust by lower units, as well observed in the Swiss Alps (Badoux, 1972 and references herein). This classically happens in gravity-driven tectonics when the uppermost units of a wedge are detached as large gravitational bodies which may slide far from their source before being in turn tectonically buried under former deeper units. Similar mechanism may explain the emplacement of the Montagne Blanches subunits within the upper flysch formations (Maurizot, 2011).

As shown in model of figure 4, we infer that in a first step, the Poya basalts have been detached from the underlying ophiolite and have experienced gravity-driven sliding along a detachment surface allowing the exhumation of deeper levels of the ophiolite. In a second step, the Poya basalts were overthrust by the rest of the ophiolitic pile, also experiencing gravity-driven sliding over its serpentine sole (fig. 4). During the advance of the Peridotite 
Nappe, compresionnal deformation may have affected the underlying units, resulting in a complex geometry of superimposed structures (fig. 4).

As reported by Cluzel et al. (2001), a striking features of the upper Eocene flysch is the progressively increasing amount of mafic ophiolitic detritus recording the approach of the Poya basalts mafic allochthon. Angular mafic clasts (i.e. basalt, dolerite and fine-grained gabbro) are widespread in breccias and their abundance and size increase upwards. These first records of the erosion of the basalts and dolerites are followed by large olistoliths which have been detached from the frontal regions of the advancing nappes during the Priabonian. The occurrence of fine-grained gabbros reflects the erosion of relatively deep levels of the mafic sequence (Cluzel et al., 2001). We assume that in the very final stage of this clastic sedimentation, the large basaltic sheets forming the basalt nappes of the Poya terrane have entirely filled up the foreland basin (fig. 4). The presence of the ultramafic-bearing Népoui flysch overlying the basalts of the Poya terrane might indicate that detrital material from the advancing Peridotite nappe has been deposited following the sedimentation of the basaltbearing clastic sequences. This transition from mafic to ultramafic sources is consistent with our hypothesis (fig. 4).

We assume that the detachment and subsequent sliding of the ultramafic sheet has been facilitated by the occurrence of a continuous serpentinite layer which developed from bottom to top, in relation with the migration of metasomatic fluids during the uplift of the metamorphic units (Ulrich et al., 2011) (fig. 4). In fact serpentinites have notoriously a soft rheology and they are classically interpreted as lubricant during tectonic processes (Moore et al., 1997; Guillot et al., 2001). The nature of the decollement level which allowed the detachment of the mafic sheet remains questionable. Assuming first an original complete mafic sequence, such as those emplaced at fast-spreading ridges, the decollement level has to be found within the lava pile itself or at the boudary between the sheeted dike complex and the lava sequence where a rheological contrast can be expected. Alternatively, the original mafic layer of the obducted oceanic lithosphere may have been formed at a slow- or intermediate-spreading center. In such a case, the dike complex may be reduced or lacking and the lavas may have been erupted directly over mantle rocks or over eroded gabbros exposed at the axial seafloor of the spreading center, as reported from investigations in 
modern oceans or in ophiolites from the Alpine belt (Lagabrielle and Lemoine, 1997; Lagabrielle 2009 with references). In this case, the decollement level might correspond to the sharp unconformity separating the lavas from the underlying oceanic basement covered with sediments.

Our model refers to a mechanism of nappe emplacement which has been the subject of considerable discussions since more than 100 years. In his synthesis about the theories and observations of nappe emplacements, O. Merle (1998) recalls that the main progresses in our understanding of the kinematics of nappes and thrust sheets have been made when scientists realized that a nappe is not a volume of rigid material displaced along an inclined surface under frictional conditions of solids. Rather, a nappe is a volume of viscous material in which any rheological analysis has to integrate the factor of time, so fundamental in geology. By integrating a plastic rheology for the bulk volume of the nappe and a layer of weak material at its base, J. Goguel (1948) showed that a nappe of three kilometers thickness can slide under its own weight on a slope of three degrees. In addition, basal detachments of some major accretionary wedges have been shown to be exceedingly weak with very low effective coefficient of friction (Suppe, 2007). The rheological parameters evoked here fall in the range of what can be expected in the case of New Caledonia. According to Guillon and Routhier (1971), the minimal thickness of the Peridotite Nappe reached indeed $2.5 \mathrm{~km}$. In addition, three degrees appears to be a possible value for the overall slope of a dome formed by the exhumed units during their ascent to the surface. Orogenic wedge average surface slopes calculated for two major orogens, the Himalaya and the Taiwan range, are of the order of $4^{\circ}$ and $3^{\circ}$ respectively (Hilley and Strecker, 2004).

Diverticulation of the ophiolitic nappes occurred in a context of overall convergence. It marks the last stages of a compressional regime and follows a long period of subduction and contraction of the Norflok continental margin. Tectonic shortening resulted in early folding of both the pre-Eocene continental basement and its Mesozoic cover as well as the Eocene flysch deposited in the foreland basin. However, the Peridotite Nappe did not record any thickening and its basal fault contact remains almost undeformed. Therefore, the peridotites have not been tectonically emplaced by a force applied to the rear. On the contratry, in the specific case of New Caledonia, we infer that the obduction occurred under a gravity-driven 
regime in response to the rapid uplift of the subduction-obduction complex linked to the exhumation of the eclogite-blueschist units of the northern region of the island.

The large impact of extensional tectonics in the overriding oceanic lithosphere through large scale normal faulting has been already reported by several authors (Rawling and Lister, 2002; Lagabrielle et al., 2005, with references; Chardon and Chevillotte, 2006; Lagabrielle and Chauvet, 2008; Ulrich, 2010). Detachment faults have been initiated in the peridotites during the initiation of the gravity sliding, and we assume that very large masses of peridotites representing the northern massifs klippes were detached from the main nappe and have slided on the roof of the basalts down to their present-day position. Initial sliding may have occurred entirely below sea level or within subaerial conditions. Tectonic fracturing allowing important water circulation is thought to trigger rapid weathering of the peridotites under both marine or continental environments. Continuous uplift during the Oligocene and the Miocene led to complete emersion of the obducted lithosphere in New Caledonia and its active weathering under subaerial, tropical environment as revealed by recent chronological data (Sévin et al., 2011).

\section{Conclusions.}

A striking feature of the New Caledonia obducted lithosphere is that the ophiolite pile lacks concordant sheeted dykes and pillow basalt layers. Moreover, the ophiolite is thrusted over basaltic formations of the Poya Terrane which were classically thought to originate from a different oceanic environment. This led most authors to propose scenarii for the tectonic evolution of this Southwest Pacific region in which the basaltic and plutonic formations originated from different oceanic basins. Based on the new petrological and geochemical results obtained from the mantle sequence of New Caledonia by Ulrich et al. (2010), we propose a simple model for the obduction of the New Caledonia ophiolite in which the Poya basalts represent the original cover of the Peridotite Nappe. Our simple model highlights the role played by slope tectonics. We assume that continuous uplift of the HP-BT units in the northern part of New Caledonia following continental subduction and possible slab breakoff, drove passive uplift of the ophiolite, and led to onset of sliding of the basaltic layer 
followed by the mantle sheet previously scalped from its mafic cover. This caused the inversion of the initial sequence in a process known as diverticulation.

The three main points which strengthen this model are as follows :

1. As early emphasized by various authors, exhumation of the HP units of northern New Caledonia occurred coevaly with the obduction of the Peridotite Nappe around 37-34 Ma. This temporal coincidence allows to envision and to discuss a cause and effect link between these two processes.

2. Boninitic dikes which intrude the Poya terrane make this unit a portion of the upper plate of the Loyalty subduction system. Therefore, the Poya basalts do not belong to the lower plate as postulated by Cluzel et al. $(2001,2012)$. The Poya basalts were overlying the mantle rocks of the Peridotite Nappe which also host slab melts dikes.

3. The basal contact of the ultramafic sheet is remarkably flat all along New-Caledonia. Moreover, the Peridotite Nappe has not been thickened during obduction, rather it experienced significant extension. This implies that the peridotites have not been emplaced by a force applied to the rear but that they experienced sliding under the force of gravity. This gravity-driven emplacement was facilitated by the development of a $100 \%$ serpentine sole during exhumation of the continental units.

Finally, the simple model presented in this article makes New Caledonia a case-study for purely passive, gravity-driven obduction processes following the subduction and contraction of a continental margin beneath a marginal basin. The oceanic lithosphere is not thrust toward the continent by rear push. Rather, the continental margin is underthrust beneath the ocean and subsequently uplifted beneath it. Additional investigations in various very large ophiolites worldwide should help establishing whether such a "passive obduction model " may fully apply to other obduction scenarii. The importance of passive uplift of ophiolitic units in response to the exhumation of HP units has been already highlighted by studies in the Oman mountains. Numerous steps in the development of this subduction orogen share clear similarities with the mechanism of passive uplift and sliding of oceanic lithosphere reported here from New Caledonia (Lippard, 1986 ; Robertson, 1987 ; Goffé et al., 1988; Robertson and Searle, 1990; Michard et al., 1994; Searle et al., 2004; Breton et al., 
6012004 ; Saddaqi et al., 2006; Agard et al., 2007 ; Yamato et al., 2007 ; Agard et al., 2010). In

602 particular, for numerous authors, tectonic processes involved in some stages of the

603 evolution of the Oman orogen refer to normal faulting and possible related gravity-driven

604 sliding. Three most representative cartoons extracted from such published models are

605 shown in figure 5 . This gravity-driven processes are the consequences of the uplift of the

606 internal units of the Arabian platform. Therefore, we assume that gravity may play a

607 fundamental role during the last stages of the emplacement of the largest ophiolitic sheets.

608 This role has not been completely deciphered yet in all the ophiolitic provinces around the

609 world.

610

\section{Acknowledgements}

612

613 Yves Lagabrielle and co-authors dedicate this article to the memory of Guy Cabioch, who,

614 besides numerous scientific tasks, studied the geology of modern New Caledonia. Guy

615 should certainly have been pleased to discuss this model with us and with others. We greatly

616 appreciated careful and constructive reviews by P. Agard, J. Collot and N. Bellahsen as well

617 as inputs from the chief-editor, O. Lacombe. Numerous discussions in the field with G.

618 Cabioch and B. Pelletier from IRD Nouméa helped clarifying some of the ideas and

619 hypotheses presented in this article. 


\section{References}

Agard, P., Jolivet, L., Vrielinck, B., Burov, E. \& Monié , P., 2007. Plate acceleration: the obduction trigger? Earth and Planetary Science Letters, 258, 428-441.

Agard, P., M. P. Searle, G. I. Alsop, and B. Dubacq, 2010. Crustal stacking and expulsion tectonics during continental subduction: P-T deformation constraints from Oman, Tectonics, 29, TC5018, doi:10.1029/2010TC002669.

Aitchison, J., G.L. Clarke, S. Meffre and D. Cluzel, 1995. Eocene arc- continent collision in New Caledonia and implications for regional Southwest Pacific tectonic evolution, Geology 23 (2) pp. 161-164.

Andrews, J.E., Packham, G.H. et al., 1975. Site 286. In: Initial Reports of the Deep Sea Drilling Project, Vol. 30. U.S.Govt. Printing Office, Washington, D.C., pp.69-91.

Arndt, N., 2003. Komatiites, kimberlites, and boninites, Journal of Geophysical Research-Solid Earth 108 (B6), pp. 1-11

Auzende, J.M., Pelletier B., and Eissen, J.P., 1995. The North Fiji basin: geology, structure and geodynamic evolution. In: B. Taylor, Editor, Back-arc basins: Tectonics and Magmatism, Plenum, NY pp. 139-175.

Avias, J., 1967. Overthrust structure of the main ultrabasic new caledonian massifs, Tectonophysics 4 (4-6) (1967), pp. 531-541.

Badoux, H., 1972. Tectonique de la nappe de Morcles entre Rhone et Lizerne. Beitraege zur Geologischen Karte der Schweiz, vol. 143. Kuemmerly and Frey, Bern, Switzerland. 78 pp.

Baker, P.E., M. Coltorti, L. Briqueu, T. Hasenaka, E. Condliffe, and A.J. Crawford. 1994. Petrology and composition of the Volcanic basement of Bougainville Guyot, Site 831. doi:10.2973/odp.proc.sr.134.017.1994.

Baldwin, S.L., Rawlings, T., Fitzgerald, P.G., 1999. Thermochronology of the northern high P/T terrane of New-Caledonia: implications for mid-Tertiary plate boundary processes in the SW Pacific. In : Baldwin, S.L., Lister, G.S. (Eds.), Penrose Conference, MidCretaceous to Recent plate boundary processes in the Southwest Pacific, Abstr. Vol., p. 13.

Baldwin, S.L., Rawling, T., and Fitzgerald, P.G., 2007, Thermochronology of the New Caledonia high pressure terrane: implications of mid-Tertiary plate boundary in processes in the southwest Pacific, in Cloos, M., Carlson, W. D., Gilbert, M. C., Liou, J. G. Rumble, D. and Sorensen, S. S., eds., Convergent Margin Terranes and Associated Regions: A tribute to W.G. Ernst: Geological of America Special Paper 419, p. 117-134, doi: 10.1130/2006.2419(06).

Black, P. M., Maurizot, P., Ghent, E. D., Stout, M. Z., 1993. Mg-Fe carpholites from aluminous schists in the Diahot region and implications for preservation of high-pressure/lowtemperature schists, northern New-Caledonia. Journal of Metamorphic Geology, 11, 455-460.

Breton, J. P., Béchennec, F., Le Métour, J., Moen-Maurel, L. \& Razin, P., 2004. Eoalpine (Cretaceous) evolution of the Oman Tethyan continental margin: insights from a structural field study in Jabal Akhdar (Oman Mountains). GeoArabia, 9, 1-18.

Cameron, W.E., 1989. Contrasting tholeiite-boninite associations from New Caledonia. In: A.J. Crawford, Editor, Boninites, Uniwin Hyman (1989), pp. 314-338.

Carson, C.J., Clarke G.L. and Powell X., 2000. Hydration of eclogite, Pam Peninsula, New Caledonia. Journal of Metamorphic Geology, 18: 79-90. doi: 10.1046/j.15251314.2000.00245.x 
Chardon, D. and Chevillotte, V., 2006. Morphotectonic evolution of the New-Caledonia ridge (Pacific Southwest) from post-obduction tectonosedimentary record. Tectonophysics, 420, 473-491.

Clarke, G. L., Aitchison, J. C., Cluzel, D., 1997. Eclogites and blueschists of the Pam Peninsula, NE New-Caledonia: a reappraisal. Journal of Petrology, 38, 843-876.

Cluzel, D., 1998. Le "flysch post-obduction" de Népoui, un bassin transporté ? Conséquences sur l'âge et les modalités de l'obduction tertiaire en Nouvelle-Calédonie (Pacifique sudouest). C. R. Acad. Sci. Paris, 327, p. 419-424

Cluzel, D., J. Aitchison, G. Clarke, S. Meffre and C. Picard, 1994. Point de vue sur l'évolution tectonique et géodynamique de la Nouvelle-Calédonie, Comptes Rendus de l'Académie des Sciences 319, pp. 683-688.

Cluzel, D., Picard, C , Aitchison, J., Laporte C., Meffre S. \&. Parat F. 1997. La nappe de Poya (ex. formation des Basaltes) de Nouvelle Calédonie (Pacifique Sud-Ouest): un plateau océanique Campanien-Paléocène supérieur obducté à l'Eocène supérieur. C. R. Acad. Sci., Paris, 324, p. 443-451.

Cluzel, D., Chiron D., Courme M.D., 1998. Discordance de l'Eocène supérieur et évènements pré-obduction en Nouvelle-Calédonie. - C. R. Acad. Sci., 327, 485-491.

Cluzel, D., J.C. Aitchison and C. Picard, 2001. Tectonic accretion and underplating of mafic terranes in the Late Eocene intraoceanic forearc of New Caledonia (Southwest Pacific): geodynamic implications, Tectonophysics 340 (1-2), pp. 23-59.

Cluzel, D., Bosch, D., Paquette, J.L., Lemennicier, Y., Montjoie, P., Ménot, R.P., 2005. Late Oligocene post-obduction granitoids of New-Caledonia: a case of reactivated subduction and slab break-off. The Island Arc, 14, 254-271.

Cluzel, D., S. Meffre, P. Maurizot and A.J. Crawford, 2006. Earliest Eocene (53 Ma) convergence in the Southwest Pacific: evidence from pre-obduction dikes in the ophiolite of New Caledonia, Terra Nova 18 (6), pp. 395-402.

Cluzel, D., Meffre, S., Jourdan, F., Maurizot, P. \& Lesimple, S. (2012). The metamorphic sole of New Caledonia ophiolite; 40Ar/39Ar, U-Pb, and geochemical evidence for subduction inception at a spreading ridge.. Tectonics, in press.

Collot, J., Géli L., Lafoy Y., Vially R., Cluzel D., Klingelhöefer D., Nouzé H, 2008, Tectonic history of northern New Caledonia Basin from deep offshore seismic reflection: Relation to late Eocene obduction in New Caledonia, southwest Pacific. Tectonics, 27(TC6006), doi:10.1029/2008TC02263.

Coltorti, M., Baker P. E., Briqueu L., Haseneka T., \& Galassi B., 1994. Petrology and geochemistry of volcanic rocks from the New Hebrides forearc region, ODP Sites 827, 829 and 830. Proceedings of Ocean Drilling Program, Scientific Results 134, 337-352.

Coudray, J., 1975. Recherches sur le Néogène et le Quaternaire marins de la NouvelleCalédonie. Contribution de l'étude sédimentologique à la connaissance de l'histoire géologique post-éocène. Thèse doct. d'Etat, Montpellier, In: Expédition française sur les récifs coralliens de la Nouvelle-Calédonie. Fondation Singer-Polignac, 8, 272 pp.

Crawford, A. J., Meffre, S., Symonds, P. A., 2003. 120 to $0 \mathrm{Ma}$ tectonic evolution of the southwest Pacific and analogous geological evolution of the 600 to $220 \mathrm{Ma}$ Tasman Fold Belt system. Geological Society of Australia Special Publication 22 and Geological Society of America Special Paper 372, 383-403.

Eissen, J.P., Crawford, A.J., Cotten, J., Meffre, S., Bellon, H., Delaune, M., 1998. Geochemistry and tectonic significance of basalts in the Poya Terrane, New Caledonia. Tectonophysics 284, 203-219. 
Fitzherbert, J.A., Clarke, G.L., Marmo, B., Powell, R., 2004. The origin and P-T evolution of peridotites and serpentinites of NE New-Caledonia : prograde interaction between continental margin and the mantle wedge. J. Metamorphic Geol., 22, 327-344.

Fitzherbert, J.A., G.L. Clarke and R. Powell, 2005. Preferential retrogression of high-P metasediments and the preservation of blueschist to eclogite facies metabasite during exhumation, Diahot terrane, NE New Caledonia, Lithos 83 (1-2), pp. 67-96.

Goffé, B., Michard A., Kiénast J.R. and Le Mer O., 1988. A case of obduction-related highpressure, low-temperature metamorphism in upper crustal nappes, Arabian continental margin, Oman. Tectonophysics, 151, 363-386.

Goguel, J., 1948. Introduction à l'étude mécanique des déformations de l'écorce terrestre. Mémoires pour servir à l'explication de la carte géologique détaillée de la France. Paris, Impr. Nationale.

Guillon, J. H., Routhier, P., 1971. Les stades d'évolution et de mise en place des massifs ultramafiques de Nouvelle-Calédonie; Bulletin du Bureau de Recherches Géologiques et Minières. Section 4: Géologie Générale, 2, 5-37.

Guillot, S., Hattori, K., Sigoyer de, J., Nägler, T. \& Auzende, A. L., 2001. Evidence of hydration of the mantle wedge and its role in the exhumation of eclogites. Earth and Planet Science Letters, 193, 115-127.

Herzer, R. H., D. H. N. Barker, W. R. Roest, and N. Mortimer (2011), Oligocene-Miocene spreading history of the northern South Fiji Basin and implications for the evolution of the New Zealand plate boundary, Geochem. Geophys. Geosyst., 12, Q02004, doi:10.1029/2010GC003291.

Hilley, G. E., and M. R. Strecker (2004), Steady state erosion of critical Coulomb wedges with applications to Taiwan and the Himalaya, J. Geophys. Res., 109, B01411, doi:10.1029/2002JB002284.

Lafoy, Y., Brodien, I., Vially, R., and Exon, N.F., 2005. Structure of the basin and ridge system west of New-Caledonia (Southwest Pacific) : A synthesis. Marine Geophysical Research, 26, 37-50. DOI 10.1007/s11001-005-5184-5

Lagabrielle, Y., 2009. Mantle exhumation and lithospheric spreading: An historical perspective from investigations in the Oceans and in the Alps-Apennines ophiolites., Ital.J.Geosci. (Boll.Soc.Geol.It.), Sezione Tematica su Alps and Apennines Vol. 128, No. 2 (2009), pp. 279-293, 9 figs.

Lagabrielle, Y. and Lemoine, M., 1997. Alpine, Corsican and Apennine ophiolites : the slow spreading ridge model. Concise review paper. C.R. Acad. Sc. Paris, 325, 909-920.

Lagabrielle, Y., Maurizot, P., Lafoy, Y., Cabioch, G., Pelletier, B., Régnier, M., Wabete, I. and Calmant, S., 2005. Post-Eocene extensional tectonics in Southern New-Caledonia (SW Pacific) : insights from onshore fault analysis and offshore seismic data. Tectonophysics, 403, 1-28.

Lagabrielle, Y. Chauvet, A. 2008. The role of extensional faulting in shaping Cenozoic NewCaledonia. Bull. Soc. Geol. Fr, 179, 3, 315-329. DOI: 10.2113/gssgfbull.179.3.315

Maillet, P., Monzier, M., Sélo, M. and Storzer, D., 1983. The D'Entrecasteaux Zone (Southwest Pacific). A petrological and geochronological reappraisal. Mar. Geol., 53: 1 79-197.

Marchesi, C., Garrido, C.J., Godard, M., Belley, F., Ferré, E., 2009. Migration and accumulation of ultra-depleted subduction-related melts in the Massif du Sud ophiolite (New Caledonia). Chemical Geology 266, 180-195.

Maurizot, P., 2011. Premiers enregistrements sédimentaires de la convergence pré- 
obduction en Nouvelle-Calédonie : Formation d'un complexe d'accrétion à l'Eocène inférieur dans le Nord de la Grande-Terre et mise en place de la nappe des Montagnes Blanches, Bull. Soc. Geol. Fr. 182, 479-491, doi:10.2113/gssgfbull.182.6.479.

Merle, O. 1998. Emplacement mechanisms of nappes and thrusts sheets. Translated by G. Keaney. Kluwer Academic Publishers, The Netherlands.

Michard, A., Goffé, B., Saddiqi, O., Oberhansli, R., and Wendt, A., 1994. Late Cretaceous exhumation of the Oman blueschists and eclogites : a two-stage extensional mechanism. Terra Nova, 6, 404-413.

Moore, D. E., Lockner, D. A., Summers, R., Ma Shengli \& Byerlee, J. D., 1997. Strengths of chrysotile-serpentinite gouge under hydrothermal conditions: can it explain a weak San Andreas fault? Geology, 24, 1041-1044.

Orloff, O, 1968. Etude géologique et géomorphologique des massifs d'ultrabasites compris entre Houailou et Canala (Nouvelle-Calédonie). Thèse, Montpellier.

Paris, J.P., 1981. Géologie de la Nouvelle-Calédonie, Mém. Bureau Rech. géol. min. 113, 1278.

Paris, J.P., Andreieff, P., Coudray, J., 1979. Sur l'âge Eocène supérieur de la mise en place de la Nappe Ophiolitique de Nouvelle-Calédonie déduit d'observations nouvelles sur la série de Népoui. C. R. Acad. Sci. Fr., Ser. D 288, 1659-1661.

Potel, S., Mahlmann, R., Stern, W., Mullis, J., and Frey, M., 2006. Very low-grade metamorphic evolution of pelitic rocks under high-pressure/low-temperature conditions, NW New Caledonia (SW Pacific). Journal of Petrology, 47, 5, pp 991-1016.

Rawling, T.J., and Lister, G.S., 2002. Large-scale structure of the eclogite-blueschist belt of New Caledonia. Journal of Structural Geology, 24, p. 1239-1258.

Ruellan, E. and Lagabrielle, Y., 2005. Subduction et ouvertures océaniques dans le SW Pacifique. Géomorphologie : relief, processus, environnement, 2, 121-142.

Robertson, A. H. F., and M. P. Searle (1990), The northern Oman Tethyan continental margin, in The Geology and Tectonics of the Oman Region, edited by A. H. F. Robertson, M. P. Searle, and A. C. Ries, Geol. Soc. Spec. Publ., 49, 3-25.

Saddiqi, O., Michard, A., Goffé, B., Poupeau, G., and Oberhansli, R. 2006. Fission-track thermochronology of the Oman Mountains continental windows, and current problems of tectonic interpretation. Bull. Soc. géol. Fr., t. 177, no 3, pp. 127-134

Searle, M. P., C. J. Warren, D. J. Waters, and R. R. Parrish (2004), Structural evolution, metamor- phism and restoration of the Arabian continental margin, Saih Hatat region, Oman Mountains, J. Struct. Geol., 26, 451-473, doi:10.1016/j.jsg. 2003.08.005.

Schellart, W.P., Lister, G.S., Toy, V.G., 2006. A Late Cretaceous and Cenozoic reconstruction of the Southwest Pacific region : Tectonics controlled by subduction and slab roll-back processes. Earth-Science Reviews, 42, 191-233.

Sevin, B., Ricordel-Prognon, C., Quesnel, F., Cluzel, D., Lesimple, S. \& Maurizot, P. (2012). First palaeomagnetic dating of ferricrete in New Caledonia: new insight on the morphogenesis and palaeoweathering of 'Grande Terre'. Terra Nova, 24-1, 77-85.

Spandler, C., J. Hermann, R. Arculus and J. Mavrogenes, 2004. Geochemical heterogeneity and element mobility in deeply subducted oceanic crust; insights from high- pressure mafic rocks from New Caledonia, Chemical Geology 206 (1-2) (2004), pp. 21-42.

Spandler, C., D. Rubatto and R. Hermann, 2005. Late Cretaceous-Tertiary tectonics of the southwest Pacific: insights from $\mathrm{U}-\mathrm{Pb}$ sensitive, high-resolution ion microprobe (SHRIMP) dating of eclogite facies rocks from New Caledonia, Tectonics 24 (3) (2005), p. 16. 
Suppe, J., 2007. Absolute fault and crustal strength from wedge tapers. Geology, 35, 12, 1127-1130. Doi : 10.11 30/G24053A.1

Titus, S.J., Maes, S.M., Benford B.,Ferré, E.C. and Tikoff, B. 2011. Fabric development in the mantle section of a paleo- transform fault and its effect on ophiolite obduction, New Caledonia, LITHOSPHERE; v. 3; no. 3; p. 221-244.

Ulrich, M., 2010. Péridotites et serpentinites du complexe ophiolitique de la NouvelleCalédonie. Etudes pétrologiques, géochimiques et minéralogiques sur l'évolution d'une ophiolite de sa formation à son altération. PhD thesis, Université de la NouvelleCalédonie, Université Joseph Fourier Grenoble. 212 p.

Ulrich, M., Picard C., Guillot S., Chauvel C., Cluzel D., and Meffre S. 2010. Multiple melting stages and refertilization as indicators for ridge to subduction formation: The New Caledonia ophiolite. Lithos, 15, 1-4. pp 223-236

Ulrich, M., Guillot S. Muñoz, M, Picard C. 2011. Origin of multiple serpentinization events in New Caledonia. AGU Abstract, fall meeting.

Whattam, S.A. 2008. Arc-continent collisional orogenesis in the SW Pacific and the nature, source and correlation of emplaced ophiolitic nappe components, Lithos 113, pp. 88114.

Whattam, S.A., J. Malpas, J.R. Ali and I.E.M. Smith, 2008. New SW Pacific tectonic model: cyclical intraoceanic magmatic arc construction and near-coeval emplacement along the Australia-Pacific margin in the Cenozoic, Geochemistry Geophysics Geosytems 9 (3)

Yamato, P., P. Agard, B. Goffé, V. De Andrade, O. Vidal, and L. Jolivet, 2007. New high-precision P-T estimates for Oman blueschists: Implications for obduction, nappe stacking and exhumation processes, J. Metamorph. Geol., 25, 657-682, doi:10.1111/j.1525-1314.2007.00722.x.

Yokoyama, K., Brothers, R. N., Black, P. M., 1986. Regional eclogite facies in the highpressure metamorphic belt of New-Caledonia. Evans, Bernard W., Brown, Edwin H. (editors), Blueschists and Eclogites, Geological Society of America Memoir, 164, 407423. 
Figure captions

839 Figure 1. Topography of the Southwest Pacific region with location of the main features

840 described in text. Topography is after the application GeoMapApp by Lamont-Doherty Earth 841 Observatory, Columbia University and NSF.

843 Figure 2. Simplified geological map of New Caledonia and two typical cross-sections of the 844 southern and northern part of the main island ( $A$ and B) (modified after Cluzel et al., 2001).

Figure 3. A simple three stages model for the development of the Loyalty subduction zone in the SW Pacific. This figure points to the chronology of opening of the South and North Loyalty basins

Figure 4. A simple model for the obduction of the New Caledonia ophiolite.

851 - Steps 1 and 2. Initiation of the Loyalty subduction at the dying Loyalty spreading center. 852 Emplacement of the pre-obduction slab melts in the upper plate (boninites and granitoids) and metamorphic evolution of basaltic units underplated from the lower plate (future amphibolite lenses). Chronological and petrological data are from Cluzel et al. (2006, 2012).

- Step 3. Inversion of the passive margin and continental subduction (red arrow). Construction of a tectonic wedge by accretion of sediments from the Norfolk margin.

857 Deposition of the Lutetian flysch, mainly calciturbidites, in the foreland basin. Rate of 858 subduction can be estimated at $6 \mathrm{~cm} / \mathrm{yr}$ assuming that $500 \mathrm{~km}$ of oceanic and $100 \mathrm{~km}$ of 859 continental lithosphere have to be subducted between 55 and $45 \mathrm{Ma}$.

860 - Step 4. Maximun depth of burial reached by the future Pouébo and Diahot Terranes.

861 - Step 5. Syntectonic sedimentation in the «lower» flysch basin and tectonic emplacement of 862 Montagnes Blanches-type subunits (MB). Erosion of the basalt layer : deposition of the 863 «upper» flysch (volcaniclastic Bourail flysch with an important mafic contribution). 864 Serpentinization of the future sole of the Peridotite Nappe assisted by fluids extracted from 865 the exhumed continental units. Uprising of the Pouébo terrane following a path allowing its 866 future structural position beneath the less metamorphosed Diahot terrane. Similar paths are 867 reported by Yamato et al., (2007), in the Oman mountains., for the highest HP grade unit of 868 As Sifha underlying the less metaporphosed units of Hulw and Ruwi-Quryat. 
869 - Step 6. Gravity sliding of the Poya basalts (PB) and unroofing of the mantle rocks.

870 Deposition of the Nepoui flysch which includes ultramafic clasts (NF).

871 - Step 7. Overall uplift of the internal New Caledonia orogen. Unroofing of the HP units dome

872 and gravity sliding of the Peridotite Nappe (PN); subsequent deformation of the underlying

873 units (Poya basalts and flysch units). Possible weathering under subaerial conditions in the

874 region of maximum uplift, including the peridotites. Normal faulting in the advancing mantle

875 unit and locally in the continental basement.

876

877 Figure 5. Selected cartoons from three different models of the evolution of the Oman

878 mountains. These cartoons highlight the role played by extensional tectonics and possible

879 related gravity-driven phenomenas during crucial stages of the emplacement of the oceanic

880 lithosphere sheet forming the current Semail Nappe. These sketches share clear similarities

881 with drawings of steps 5 to 7 , in fig. 4.

882 


\section{Légendes des figures}

884 Figure 1 . Topographie de Sud-Ouest Pacifique et localisation des principales structures 885 décrites dans le texte. Carte dressée grâce à l'application GeoMapApp du Lamont-Doherty 886 Earth Observatory, Columbia University et de la NSF.

Figure 2. Carte simplifiée de la Nouvelle-Calédonie et deux coupes représentatives au nord et au sud de l'île (A et B) (modifié d'après Cluzel et al., 2001).

Figure 3. Modèle en trois étapes de l'établissement de la subduction des Loyauté. Cette figure montre la chronologie de l'ouverture des bassins Sud- et Nord-Loyauté.

Figure 4. Un modèle simple de l'obduction en Nouvelle-Calédonie.

895 - Etapes 1 et 2. Début de la subduction des Loyauté au niveau du centre d'accrétion inactif du 896 bassin Sud-Loyauté. Mise en place des magmas pré-obduction issus de la fusion du slab et 897 métamorphisme d'une partie de la plaque plongeante pour donner les futures amphibolites.

898 Les données pétrologiques et géochronologiques sont de Cluzel et al., (2006, 2012).

899 - Etape 3. Inversion de la marge passive du bloc de Norfolk et subduction continentale (flèche 900 rouge). Construction d'un prisme tectonique par accrétion des sédiments de la marge de 901 Norfolk. Dépôt du flysch lutétien dans la bassin d'avant-chaîne. On peut envisager un taux de 902 subduction de $6 \mathrm{~cm} / \mathrm{an}$ en admettant que $500 \mathrm{~km}$ de lithosphère océanique et $100 \mathrm{~km}$ de 903 lithosphère continentale ont été subduits entre 55 et $45 \mathrm{Ma}$.

904 - Etape 4. Stade pour lequel les futures unités de Pouébo et du Diahot ont atteint leurs 905 profondeurs maximales d'enfouissement.

906 - Etape 5. Sédimentation syntectonique dans le bassin du flysch "inférieur" et mise en place 907 tectonique des unités de type "Montagnes Blanches" (MB). Erosion de la couche basaltique 908 de l'ophiolite et dépôt de l'ensemble du flysch "supérieur" (flysch volcanoclastique de Bourail 909 caractérisé par une forte contribution mafique). Serpentinisation de la future semelle de la 910 Nappe des Péridotites assistée par des fluides s'échappant des unités continentales sous911 jacentes en cours d'exhumation. Remontée des unités de Pouébo selon un trajet permettant 912 leur future position structurale sous les terrains moins métamorphiques du Diahot. Des 913 trajets semblables sont décrits par Yamato et al., (2007) en Oman pour les unités de As Sifha, 
914 situées sous les unités moins métamorphqiues de Hulw et Ruwi-Quryat.

915 -Etape 6. Glissement gravitaire de l'unité des basaltes de Poya (PB) et décoiffement des

916 péridotites. Dépôt du flysch de Népoui (NP) qui remanie localement du matériel ultrabasique.

917 - Etape 7. Surrection d'ensemble de l'orogène néo-calédonien interne. Décoiffement du dôme

918 d'unités de haute pression et glissement gravitaire de la nappe des péridotites (PN).

919 Déformation induite des unités sous-jacentes (nappe de Poya et flysch). Altération possible

920 en condition sub-aérienne de la région de soulèvement maximal, y compris des péridotites.

921 Tectonique extensive en failles normales possible dans la nappe en cours d'avancée et dans

922 le soubassement continental.

923

924 Figure 5. Schémas tirés de trois modèles d'évolution des montagnes d'Oman. Ces dessins

925 illustrent le rôle joué par la tectonique extensive et les phénomènes tectoniques gravitaires

926 durant des stades importants de la mise en place de la lithosphère océanique formant

927 aujourd'hui la nappe de Semail. Ces figures montrent de nettes ressemblances avec les

928 dessins des étapes 5 à 7 de la figure 4.

929 


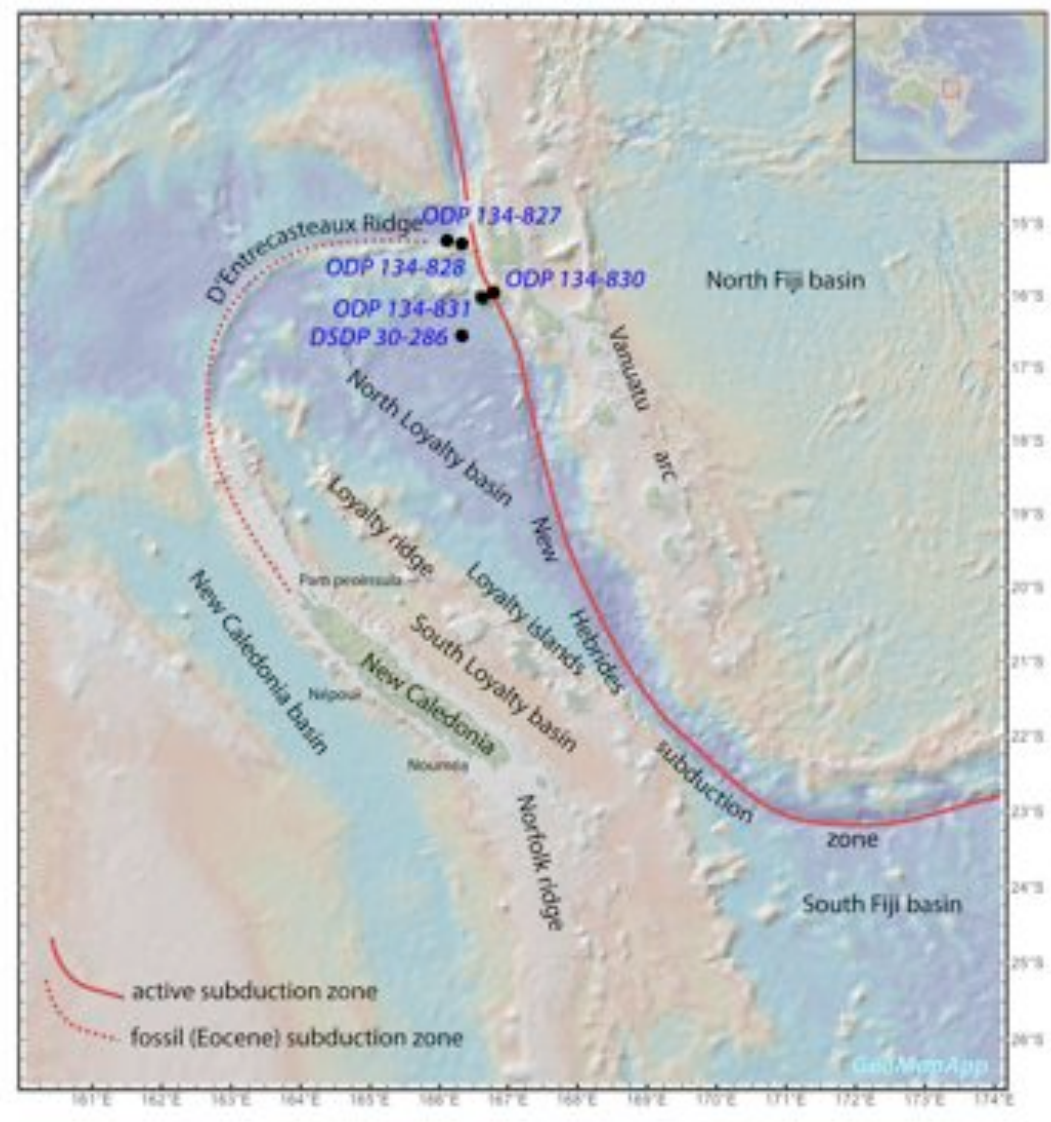

Lagabrielle et al_ fog. 1 

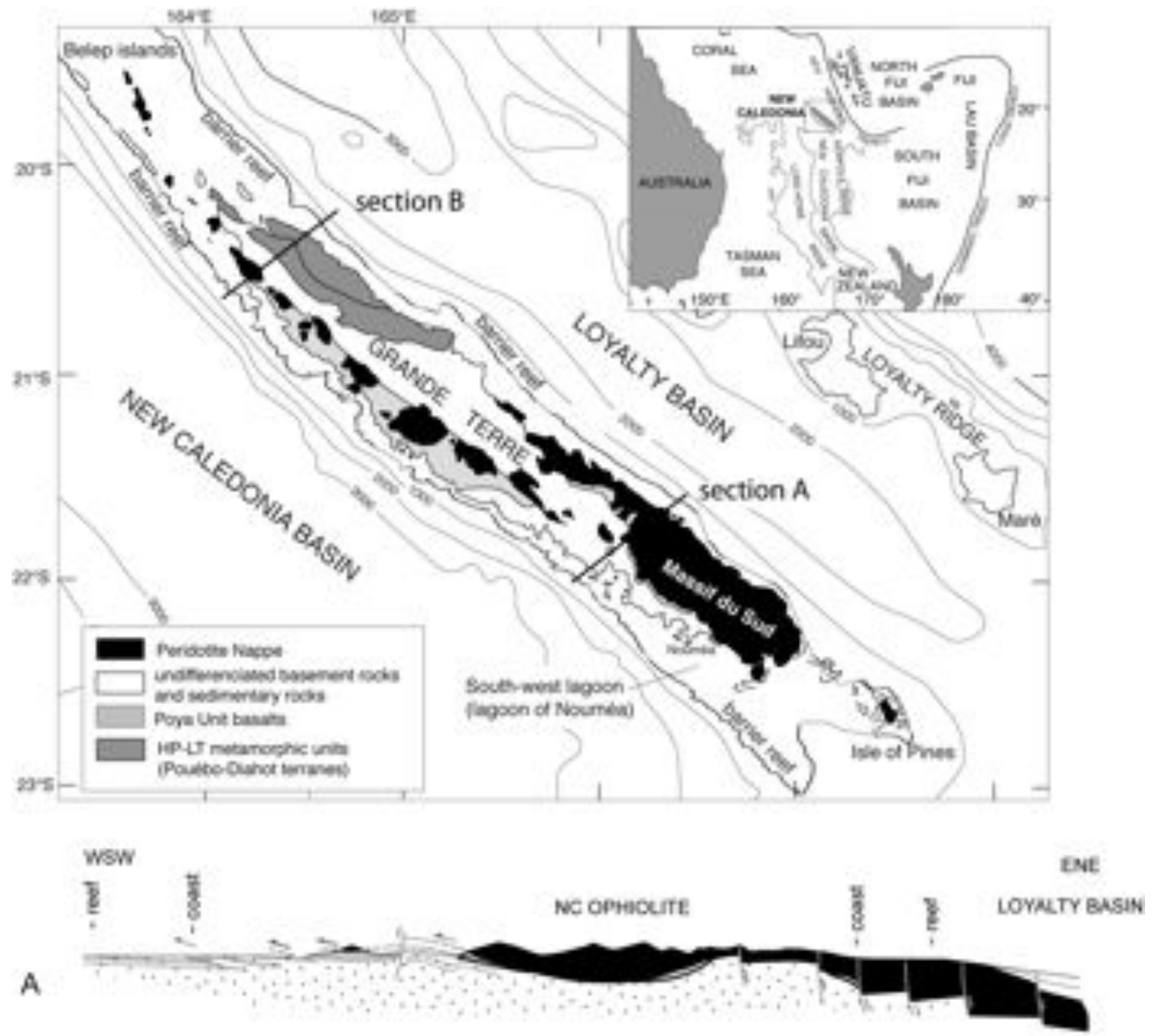

sw

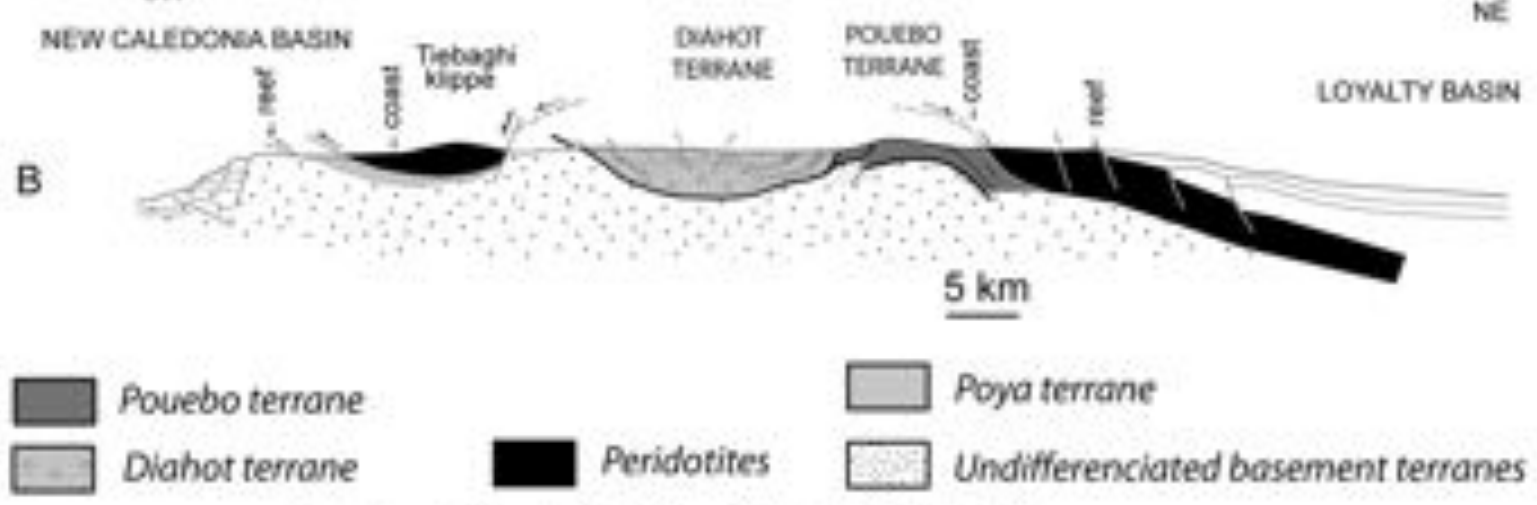

section $A$ and $B$ modified from Cluzel et al. (2001) 

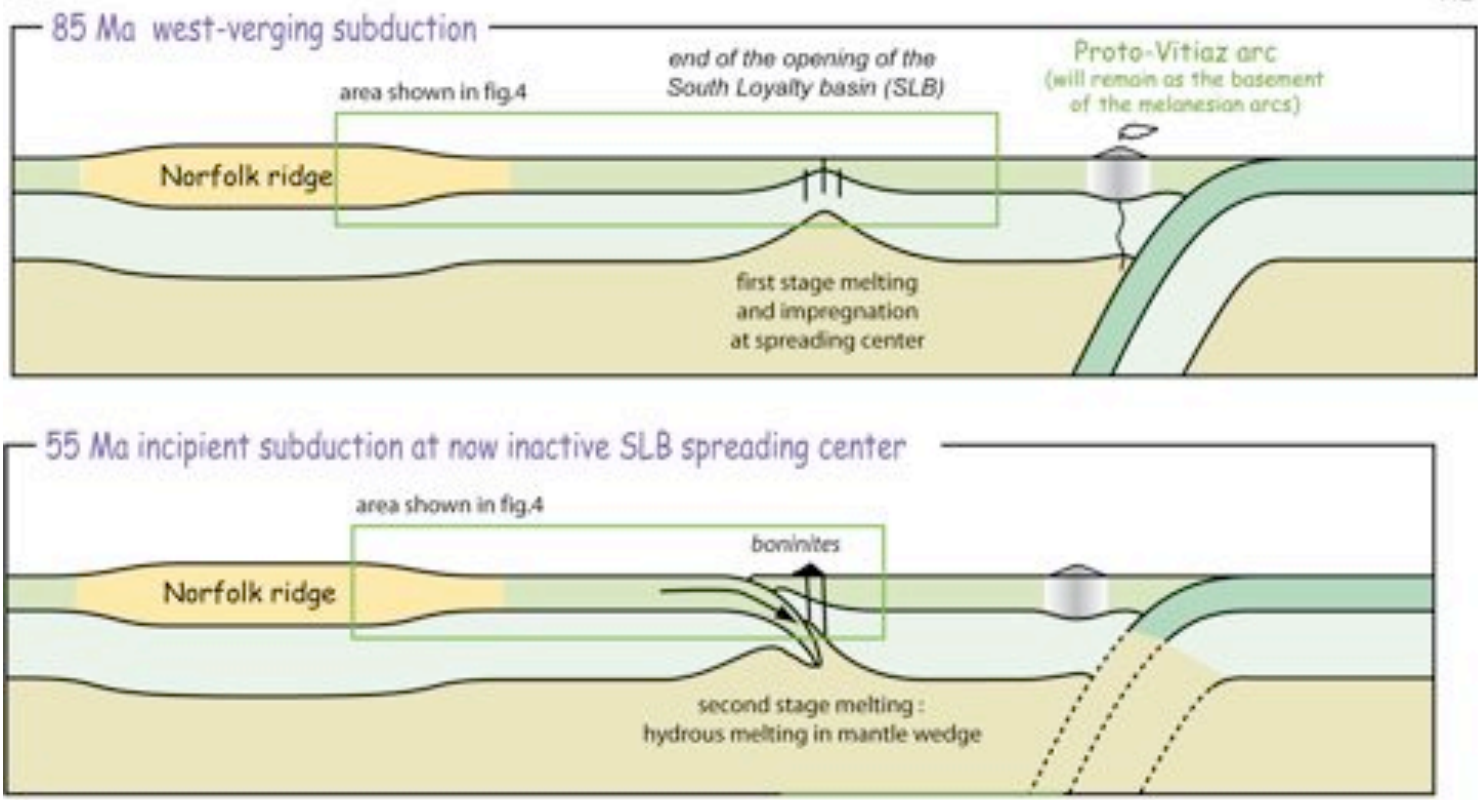

$40 \mathrm{Ma}$ incipient subduction of the Norfolk continental margin and passive obduction of the eastern part of the SLB
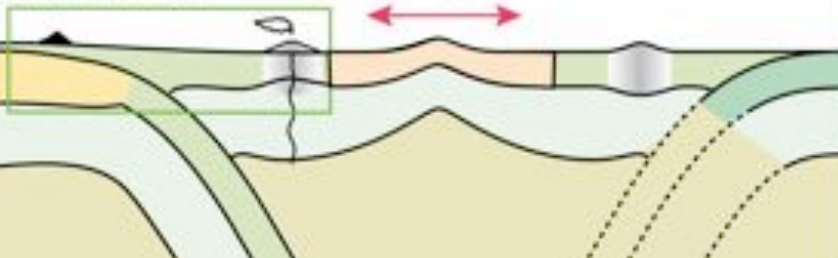
w-sw

Nortolk beock eastem cominental margin

South Loyality bavin

e-Ne

\begin{tabular}{l}
$160 \mathrm{Ma}$ Paleocene \\
\hline $255 \mathrm{Ma}$ Ypresian
\end{tabular}

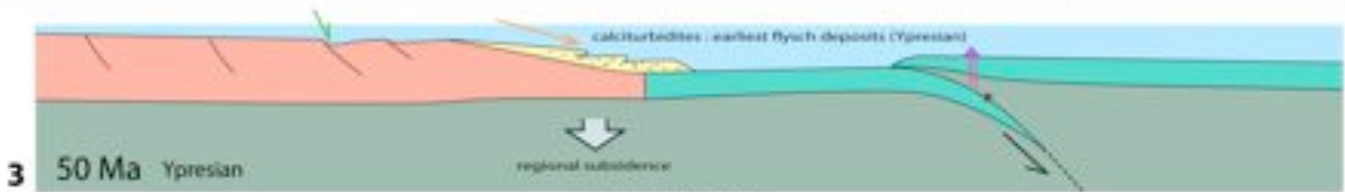

$350 \mathrm{Ma}$ Ypresian

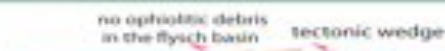
ntion on foreland tasin

$445 \mathrm{Ma}$ utetian not to scale thrust fault $\quad$ normal faulting (contractional tectonics) [extemsional tectonics)

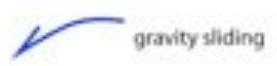

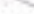

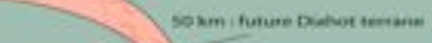
dastic sedimentation 
40 Ma MAJOR CHANGE : SHIFT FROM CONVERGENCE AND HORIZONTAL CONTRACTION TO DOMINANT VERTICAL MOTIONS AND EXHUMATION OF BURIED UNITS

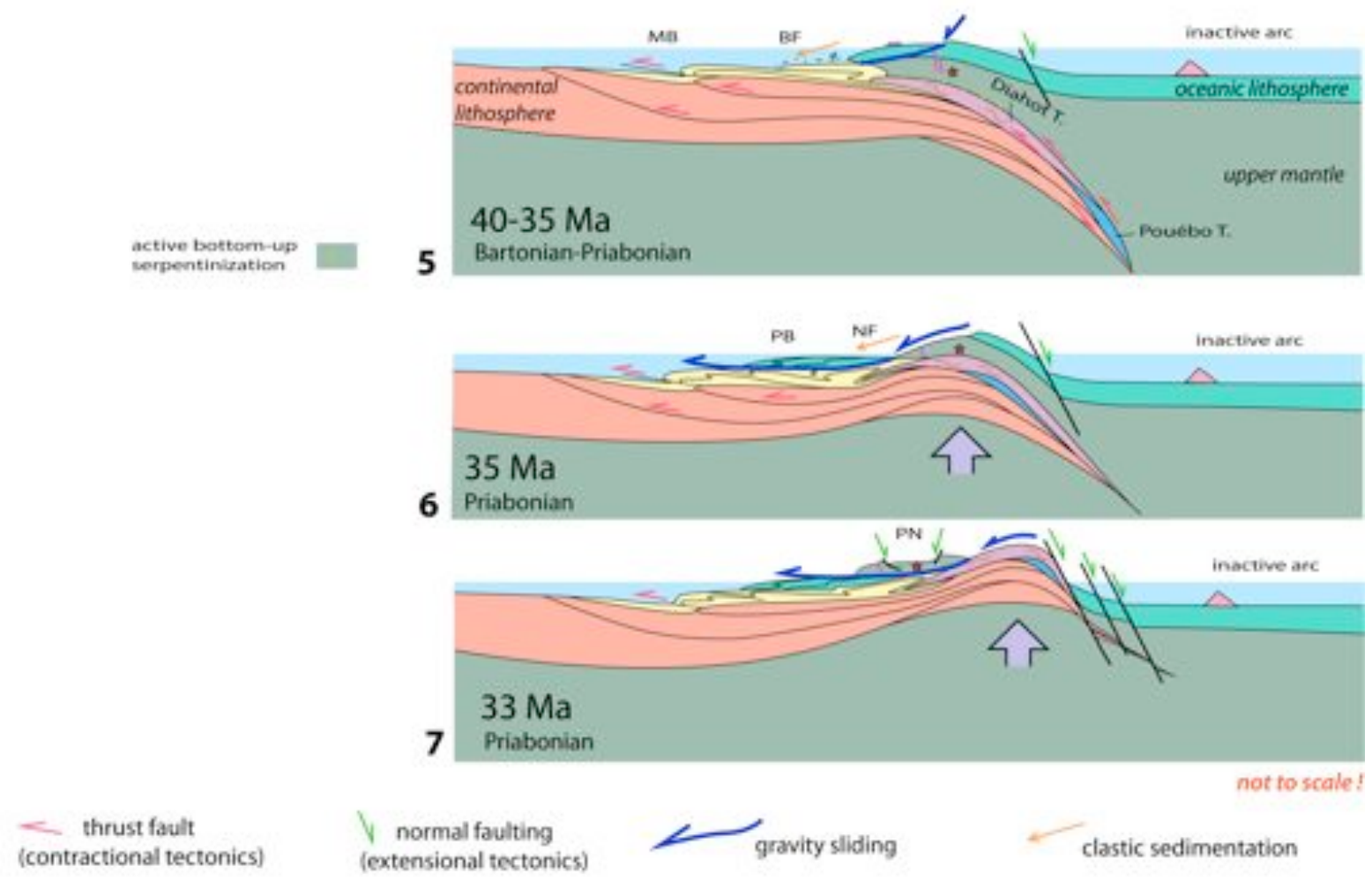



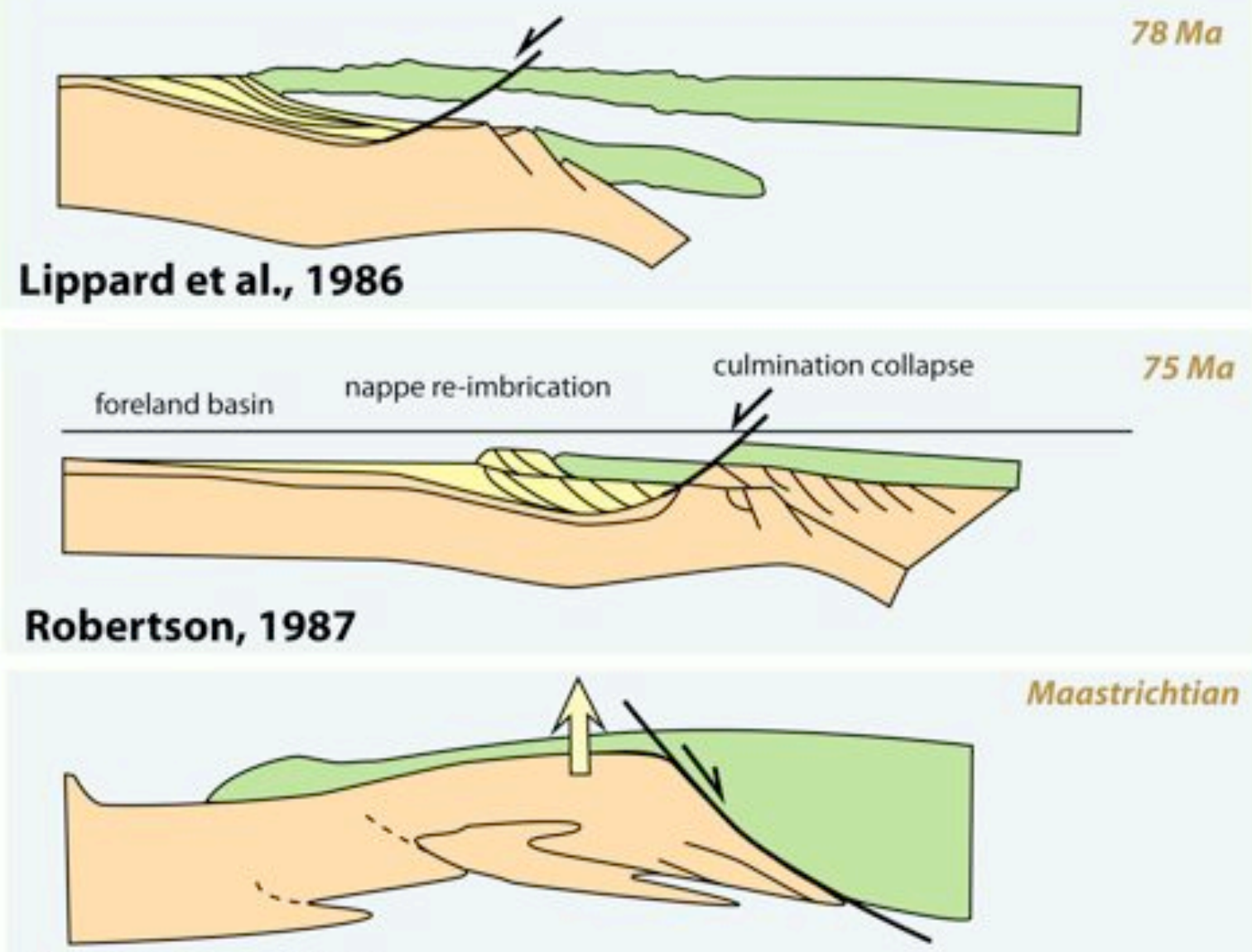

Maastrichtian

Agard et al., 2012

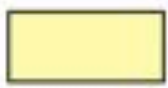

orogenic sediments

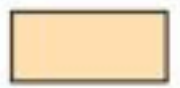

continental crust and/or lithosphere

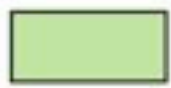

oceanic crust and/or lithosphere 